Jurnal ASPIKOM, Vol. 6, No. 1, January 2021, pp. 122-135

P-ISSN: 2087-0442, E-ISSN: 2548-8309

DOI: http://dx.doi.org/10.24329/aspikom.v6i1.847

\title{
Political Rhetoric of East Java's Governor and Deputy Governor Candidates
}

\section{Retorika Politik Calon Gubernur dan Wakil Gubernur Jawa Timur}

\author{
Anang Sujoko 1 \\ ${ }^{1}$ Universitas Brawijaya, J1. Veteran, Ketawanggede, Malang \\ *Corresponding author, e-mail: anangsujoko@ub.ac.id
}

\begin{abstract}
Public debate is one of the stages in a General Election determined by the Commission of Election (KPU) to present the vision, missions, ideas, and programs of prospective leaders to the public. Political rhetoric is a specific study on how political actors try to persuade or attract public voters' sympathy. This study aimed to reveal Governor and Deputy Governor candidates' rhetoric in the 2018 East Java Public Debate, using an interpretative qualitative research method with political rhetorical analysis from Finlayson. This study used documentation techniques of the broadcasted recording of Public Debate I, II, and III by TVRI Surabaya and JTV Surabaya for the data collection. The study results indicated that the two candidates for Governor and Deputy Governor of East Java in 2018 had their respective political rhetoric strategies in persuading prospective voters when the Public Debate took place, started from the context contestation; candidate character in rhetoric; contestation perception; and ideological contestation.
\end{abstract}

Keywords: Governor Election; Public Debate; Political Rhetoric

\begin{abstract}
Abstrak
Debat Publik menjadi salah satu tahapan Pemilu yang ditetapkan oleh KPU dalam rangka menunjukan visi dan misi, gagasan, serta program dari calon pemimpin kepada publik. Retorika politik merupakan kajian khusus yang mengkaji tentang bagaimana aktor-aktor politik berupaya mempersuasi atau menarik simpati publik calon pemilih. Penelitian ini bertujuan untuk mengungkapkan retorika calon Gubernur dan Wakil Gubernur di Debat Publik Jatim 2018, untuk mengungkapkan hal tersebut penelitian ini menggunakan metode penelitian kualitatif interpretatif dengan teknik analisis retorika politik dari Finlayson. Teknik pengumpulan data dalam penelitian menggunakan teknik dokumentasi, yakni rekaman siaran Debat Publik I, II dan III oleh TVRI Surabaya dan JTV Surabaya. Hasil dari penelitian ini menunjukan bahwa kedua calon Gubernur dan Wakil Gubernur Jatim 2018 memiliki strategi retorika politik masing-masing dalam mempersuasi calon pemilih ketika Debat Publik berlangsung, mulai dari konteks kontestasi; karakter kandidat dalam beretorika; kontestasi persepsi; dan kontestasi ideologi.
\end{abstract}

Kata Kunci: Debat Publik, Pemilihan Gubernur, Retorika Politik 


\section{Introduction}

Scholars at the beginning of the 21 st century have reintroduced rhetoric and argumentation for political analysis. In contrast to the traditional approach toward rhetoric regarded as a type of speech, they treat rhetoric not only as an object of study but also as the basis of the analytical framework for political language study. Finlayson, Martin, and Atkins have developed this new approach -Political Analysis of Rhetoric- to study political language, ideology, and strategy (Atkins \& Finlayson, 2013; Finlayson, 2012; Finlayson \& Martin, 2008). Their research aims not only to contribute to the study of the political sphere in conceptualizing political language as rhetoric but also to demonstrate the benefits of using the rhetoric concept in analyzing political language. The main emphasis of this approach is the persuasive dimension of political language. Regarding the rhetorical political analysis, political rhetoric has a counterpart in the post-positivist study of public policy, which emphasizes the argumentative nature of policy discussion as opposed to the instrumental-rational model of decision making (Fischer, 2003; Fischer \& Gottweis, 2013; Gottweis, 2017; Turnbull, 2017).

The similarity between the two approaches is to see a more significant role of rhetoric in accepting epistemological contingencies and in the account for the practical purposes of political discourse found in dynamic exchanges between speakers and attendees. In the perspective of ritual communication, rhetoric as communication is an activity of sharing and transactions between all parties involved in it. Rhetoric should not only focus on the communicator, but also both parties' participation is very decisive in the communication process (Carey, 2009). Thus, we can distinguish such positions as a thick approach to political rhetoric. This approach is different from other more limited approaches, which perceives rhetoric as a technique from mere speech (Crines, 2013; Crines Hayton, 2015) and aims to persuade the audience (Condor et al., 2013). One in the latter conception reflects the traditional idea that rhetoric is a technical discipline regarding the organization and delivery of speeches, often focused on speech. Despite the renewed interest in rhetoric and its extension to a more in-depth analytical approach in politics, most scholars who study political language prefer to use an analytical approach other than rhetoric (Walter, 2016). Furthermore, they use this approach as a substitute for 'political communication', 'discourse analysis' or 'narrative analysis' for some reasons.

Firstly, it is methodically acceptable in academic culture. In contrast, a rhetorical analysis is very interpretive and allows significant variations in the interpretation of meaning, broad and too numerous in contribution to the generally accepted analytical framework. Secondly, the three adopted approaches above seem to treat language and ideas in greater depth than those implied by the characterization of dominant and thin rhetoric, which occupies the surface area of language. Thin rhetoric approach means the researcher will analyze how the sender transmits a message to the audience and how the communicator employs language to persuade and influence the audience. In other words, rhetoric is the art of persuasive technic.

Meanwhile, thick rhetoric approach treats language. It will be better to provide a brief explanation of thin and thick rhetoric approach. Thus, they are not worthy of an indepth investigation. Despite the argument that, in general, the 'rhetorical bend' can be identified in social sciences, the rhetoric of inquiry is an intellectual movement (Struever, 1993); the talk of 'curves' itself is little more than strategic intellectual rhetoric. In any case, shreds of evidence, such as trajectories in social science, are very limited. A thick approach to rhetorical analysis needs to strengthen both methodological 
and substantive dimensions. Today, the theory of thin rhetoric dominates. Rhetoric is appearance, not substance or decoration. I agree with this explanation because it illustrates the urgency of the author's Rhetorical Politic Analysis Technique. There is a novelty that is brought out by comparison with other approaches.

This paper aims to support and broaden a thick perspective by developing a new conception of rhetoric and rhetorical analysis. A new rhetorical theory, which is a general concept of language, was introduced while instilling rhetoric in the relational account of language. Thereby, it supports the notion that rhetorical analysis is a consistent methodology with another sub-discipline: political science. The resulting conception is one that aims to overcome the partial theory of political rhetoric in support of general views, while at the same time presenting rhetoric as an aspect of political analysis, and consequently rejecting the rhetorical view as an autonomous discipline. The theory of rhetoric must be extended beyond theories that limit its definition of persuasion and argumentation. It must take into account the figurative and argumentative dimensions of language, and it explains how rhetoric is utilized figuratively to produce unity while bridging differences through discussion.

By competing with the conception of political rhetoric and argumentation, rhetoric as an object of rhetorical political analysis has been analyzed primarily as an object of political analysis. Thus, it has been conceptualized in terms of specific speech genres or as a set of techniques, often limited to speech and oriented towards persuading audiences in a discussion process (Hay, 2013; Martin, 2015), or best as companions to make arguments with their effectiveness (Fairclough \& Fairclough, 2013). Political speech by leaders is the most obvious example. The ability to persuade other political actors and the public had always been vital for leaders in elections to get, use, and maintain daily power, or in parliamentary debates concerning persuasion as a better force of arguments and also as a contest between the ethos of opposed leaders (Husain, 2011; Tilly \& Goodin, 2006).

A general election mechanism that includes the election of Mayors/Regents, Governors, and President has provided a stage that allows prospective voters to familiarize themselves with how each election contestant in an open debate event (Republic of Indonesia's Election Commission Regulation Number 4 of 2007). Open debates facilitated by the Commission of General Election (KPU) or Regional Commission of Regional Election (KPUD) become very notable events in testing candidate pairs' ability in managing communication over their future programs. According to KPU regulations, public debates aired by broadcasting institutions are expected to be public witnesses for candidates when they are elected to fulfill their promises. However, public witnesses do not have strong control over the elected candidates, and the debates are merely for political entertainment. For example, according to Sulaiman (2014), the Presidential Election Debate will not significantly discover candidates' vision and mission; this program just shows how candidate speech better than others. It means this debate program tends to show the appearance of the candidate than the content of their message. Therefore, regional representative council members can use this research to evaluate how strong the elected candidates commit to realizing what they said and promised. Is there any problem to be solved by this research? The author should provide data to convince us concerning the problem.

In the Governor and Deputy Governor's Debate of the 2018 East Java Election, the political contestation offered old figures who had competed twice in the same event of the previous two periods, namely Khofifah and Saipul (Gus Ipul). Previously, Gus 
Ipul was a deputy governor candidate from Soekarwo, and Khofifah was a governor candidate. In 2018, Gus Ipul was head to head with Khofifah as a governor candidate. In the East Java Provincial Election in 2018, only two pairs of candidates participated, namely Khofifah-Emil and Gus Ipul-Puti, both of which had significant powers on an NU (a Public Organization) basis. Gus Ipul's two-period background as Deputy Governor of East Java supported by an NU-affiliated party (PKB), considered to have inherent strength in supporting the vote to win the election. Meanwhile, Khofifah-Emil supported more political parties (Golkar, Demokrat, Nasdem, Hanura, PAN, and PPP), and close to the Muslimat community (NU women's mass organization) also had advantages since they experienced as a minister and regional head. In two Public Debates, the polls showed the superiority of Gus Ipul-Puti pair (www.pollingnasional.com); meanwhile, in the political analysis by observers, Khofifah was indicated to obtain debating confidence which was capable of boosting the numbers of votes (Soedjatmiko, 2018).

\section{Method}

This study aimed to reveal the strategy of two candidate pairs in the 2018 East Java Governor and Deputy Governor Election through a political rhetoric analysis in Public Debates I and II broadcasted by TVRI. Based on the objective, this study is categorized as a qualitative research type. Qualitative research aims to describe the data of research results in great detail through intense data collection (Kriyantono, 2006). The research method is qualitative with an interpretive paradigm. Neuman (2013) described Interpretative social science (ISS) as an analysis approach that systematically perceives the meaning of social actions through direct and detailed observations under a scientific setting. The researcher interpreted the debate transcript by relating the former positions of the candidates and how they argued. In this interpretation process, understanding communication context and social or political situation can help the researcher enrich the interpretation result.

The interpretive paradigm is expected to provide an understanding and interpretation of how people create and defend their social world (Neuman, 2011). The study's data sources were sequential Public Debate video recordings broadcasted live by TVRI and JTV Surabaya (first to third recordings). The data collection technique was documentation, namely the recordings of Public Debates I, II, and III broadcasted by TVRI Surabaya and JTV Surabaya Stations. The obtained data were analyzed with the Rhetorical Politic Analysis technique described by Finlayson (2007, 2012, 2013).

The researcher analyzes the interpretation based on the elements of the analysis of political rhetoric techniques consisting of rhetorical situations, arguments, and general features. However, this article does not discuss only rhetorical situations because each candidate had a turn to speak in this debate, which was arranged by the host. The rhetorical situation element shows how the debate occurs and the context behind the debate. Meanwhile, the argument element has more detailed sub-elements related to the type of argument, content substance, ethos, and logos. In stasis theory, the types of arguments will be detailed into conjecture, definition, quality, and commonplace. Finally, in the general feature elements, the researcher analyzes the sentence types and diction in the speeches. 


\section{Results and Discussion}

This section presents several categories: Contestation Contest: Vision, Mission, and Work Program; Candidate Character; Contestation of Perception; and Contest of Ideology. In the Contest of Contestation: Vision, Mission, and Work Program, we will find out how the formulation of the vision, mission, and program cannot be separated from the public position of each candidate. The diction in each presentation reflects how each candidate wants to show success in his public office. Further details on how to construct an argument as a strategy can be found in the Candidate Characters section. In the Contestation Perception, each candidate plays a common problem framing and logo to ensure the candidate has the ability to lead East Java to a better future. How do the candidates redefine the problems, position, and potential of East Java in an archipelago country and the type of leader East Java deserves as a governor and vice-governor. In the end, the Ideology Contest provides information regarding the ideology of the supporting political parties in each candidate pair and does not show any significant differences between the two pairs of candidates.

\section{Contestation Context: Vision, Mission, and Work Program}

Vision, mission, and work programs are essential keys in political contestation. To compete for voters' support, each candidate tries to offer programs so that prospective voters can accept them. In the contestation of the East Java election for 2018-2024 Governor and Deputy Governor, each candidate carried a different vision and mission. Khofifah-Emil's vision is realizing the prosperous, balanced, superior, and moral East Java society under the participatory, inclusive governance which was respectful to humanitarian values. Meanwhile, candidate pair number two, Gus Ipul-Puti, offered a vision of sustainable change for prosperous East Java.

That two candidate pairs carried two visions indirectly showed different characters of each Governor and Deputy Governor candidate. The narrative developed by Khofifah-Emil tended to use a relatively high academic language. Meanwhile, Gus Ipul-Puti narrated the vision by using modest language. Khofifah-Emil's academic language was represented by using words such as participatory and inclusive, which were typical for intellectuals. Their vision was influenced by an Islamic approach where the moral substance was included as a part of efforts to perform development.

In contrast, Gus Ipul-Puti put their vision as a determination to continue the ormer government programs of Gus Ipul as the previous Deputy Governor. The second pair was relatively benefited as the incumbent, considering that programs that had been implemented in the consecutive period and recognized as the ones who could still be offered and feasible. In contrast, these benefits could be relatively ineffective when people highlighted that the previously implemented programs were considered less successful.

Political narratives were built from vision and mission and from offering work programs that became competitive contestation. Both parties tried to persuade the public. Khofifah-Emil presented their work program as Nawa Bhakti Satya (in the Sanskrit language), while Gus Ipul- Puti emphasized a unique naming (abbreviation) in each program (see Table 1). 
Table 1. The Work Program of Two Candidates

\begin{tabular}{cc}
\hline & Work Program \\
\hline Khofifah-Emil & Gus Ipul-Mbak Puti \\
\hline Bhakti 1: Prosperous East Jawa & Dik Dilan (Continuous Free Education) \\
\hline Bhakti 2: Working East Java & Sustainable Plus Madin \\
\hline $\begin{array}{c}\text { Jhakti 3: Smart and Healthy East } \\
\text { Baras Hati (Services which are Even, } \\
\text { Qualified, Healthy, and Innovative) }\end{array}$ & \begin{tabular}{c} 
Rembulan (Programs for Women and Elderly) \\
\hline Bhakti 4: East Java Access
\end{tabular} \\
\hline Bhakti 5: Blessed East Java & Prosperous Artists) \\
\hline Bhakti 6: East Java Agro & Superstar (Center for SME and Start-Up \\
Empowerment)
\end{tabular}

\section{Candidate's Characters:}

\section{Khofifah Indah Parawansa - A Courteous Visionary}

Khofifah Indar Parawansa, or familiarly called Khofifah, is a polite visionary. She provided alternative solutions to build the East Java government. Through several experiences in the bureaucratic world where she lived, she positioned herself to appear optimistic to influence regional development significantly. This optimism was built with courtesy through respect for existing government achievements and constructive input.

Khofifah's sympathetic character was reflected in the public debate of East Java Election. She chose to use the term "Gus" to greet his political opponent, Saifullah Yusuf. Mentioning the term "Gus" became a greeting of respect as a part of Nahdliyin's circles. It was related to Khofifah as one of Nahdhatul Ulama (NU) Muslimat leaders. Her modesty and kindness were also felt in the suffix use of "panjenengan" and "Mbak". The term "panjenengan" was full of Javanese noble values, which means an effort to place other people more noble or primary, while the term "Mbak" does not refer to older people in this context, but as ethics so as not to directly call one's name.

Khofifah was known as an active person. Several vital positions in the government bureaucracy ranks had once been occupied. It affected the use of bureaucratic diction when giving her views in the debate. For example, during the first debate, she started with strategic public issues such as BOSDA education funds to be discussed. Khofifah was very empowered in the issues through diction such as "integrated services" and "bottom-up participation". It supports her work as a Minister of Social Affairs at that present time.

In the context of public debate, Khofifah chose to be critical instead of provocative. Interesting. Despite her background experience as a minister, as an influencing leader of the largest Islamic women's organization in Indonesia, a critical attitude strategy is considered to have a better impact and is also a way of respecting political opponents who are still under the umbrella of the same organization, NU. The critical stance is presented using narrative composing techniques so that it is no longer only easy to accept in a sense (logos) but also has a natural impression. The impact of 
this strategy is that in addition to showing the opponent's weakness based on data, it will also show the public that she is better than her opponent. This point shows how political rhetoric analysis works on the basis of robust data and differs from rhetoric in general, where the arguments are often based on fiction (Finlayson, 2007). Further mentioned, she did not "hesitate" to appreciate several favorable policies during the incumbent's reign. Critical non-provocative views are reflected in several terms, such as "Miss Puti must go down again" and "Governor regulation is hastened". The first term was used when Khofifah responded to Puti's answer relevant to internet connectivity in East Java, deemed inappropriate. At the same time, the Governor regulation context was utilized as a criticism for the incumbent, who was considered less responsive in overseeing policy regulations.

When Khofifah spoke about poverty, she did not directly point to the failure of Saifullah Yusuf as the part of the incumbent who became his opponent. However, she preferred to ask by highlighting the substantive aspect of inequality when describing poverty levels in East Java, primarily rural areas. Then, she asked Gus Ipul (her opponent), "during the position as the Deputy Governor, what have you been doing responding to poverty issues?" Khofifah's argument in the context of attacking an opponent (baiting) was indirect. She did not try to "exploit the problem" to justify the failure of the opponent. Instead, she chose to keep asking about the past performance implemented.

The choice of Khofifah's terms was more directed to academic nuances, supported by practical experience, which relied on the mastery of the problem. In controlling this problem, besides narrating it with statistical data such as BPS, she also completed it by making direct efforts to society. In addition to academic diction, Khofifah also used populist diction to show that she provided partiality to society's lower classes. It was reflected in the diction or terms of "prosperous people," "healthy people," "educated people," and "people have rights."

Khofifah did not prefer to emphasize the track record. She would rather like the real aspects related to providing alternative solutions. Her assistance for local economic empowerment supported by her consistent improving offers became her strength presented in the public debate space. She chose to use the metaphor of "Breath to build East Java" or "Heart of the Republic" to support the public's emotional spirit when delivering vision and mission. Also, the nuances of nationalism and optimism building the future reflected by rhetorical statements "The successor to the greatness as well as glorious archipelago" and "Guarding and protecting the Homeland." In general, Khofifah had main characters, such as polite, systematic, active, and critical thinking. In this debate, her speech did not aim to persuade audiences (Hay, 2013; Martin, 2015), but naturally show that she is a well-educated person who has a strong Islamic background. These characters influenced the selection of terms when conducting public debates. Khofifah's rhetorical style to choose the greeting word "Gus" and use data critically and fairly in appreciating the opponent's achievements shows a figure who has intellect, credibility, and charisma (Struever, 1993; Bligh, Kohles, and Meindl, 2004). Contradictory, some attributes that highlight Khofifah's trait were somewhat different from Emil Dardak as his political partner and Puti as her political opponent.

\section{Emil Elestianto Dardak - Intellectual Professional}

Emil Elestianto Dardak or Emil Dardak is an intellectual, professional figure. He appeared critical with academic approaches. His experience at the international level and as a Ph.D. holder, an indication of his academic capacity, triggered a significant 
influence. He used measurable data-based parameters to provide productive arguments.

Emil had a critical attitude based on academics. It was indicated by the terms he used to give his views and respond to his political opponents' statements. Terms such as "BPS Check" and “Check Time Series Analysis' indicated that he was very close to data and conceptual references of the issue being debated. Even if a political opponent provided a less relevant view, he was not reluctant to attack or express criticism firmly. For example, when he attacked Puti as the deputy governor candidate who incidentally had been in Commission X, he viewed that Puti was not successful in carrying out her role to revise the appropriate Education System Law.

Emil's implicit attitude in responding to his political opponents showed that he was intelligent. He was able to break the arguments of opponents who were considered not to know the substance of the problem and provide understanding in a broader sense. Emil had high confidence. He alluded to the record of his success several times when leading Trenggalek Regency by illustrating that he wanted to present himself as a proficient person. Emil used the achievement record to strengthen his existence and evaluate his political opponents' achievements, especially Puti, who was considered unsuccessful in carrying out her role in Commission X.

Emil was perceived to possess the Western way of thinking and progressiveness. He underwent education to become a professional. His international experience, which brought him into a quantitative thinking space, led him to adjust to specific standards or parameters. Western thinking style indeed emphasized the existence of measurable aspects to be encountered. Furthermore, Emil seeks to minimize the drawbacks of the "eastern" and "hierarchical" culture, which he considered less appropriate in building a good-governance climate. Emil's understanding of building good governance referred to the performance as a measurable output rather than prioritizing personal attachment, which had been a dominant challenge in bureaucratic culture. During the public debate, he wants to argue effectively (Fairclough \& Fairclough, 2013), and sometimes he attaches to his opposite candidate emotionally.

Finally, Emil presented himself as an innovative and broad-minded individual, shown by idealistic conceptual-practical discourse in the debate in the theme of "Industry 4.0" to be a government discourse in responding to the rapid challenges in communication, information, and technology. Adding to that of the intellectual attributes, his broad experience in several countries, such as Korea, had provided a frame of reference in creating applicative innovations in the realm of bureaucracy.

\section{Saifullah Yusuf - Religious Nationalists}

The figure of Saifullah Yusuf or Gus Ipul was a religious-nationalist. The spirit of nationalism supported the tendency for the use of santri terms. He appeared as a moderate, and confident Muslim figure who put forward the humanist side to develop East Java.

His figure was not peculiar to East Java people. The incumbent Deputy Governor had accompanied Soekarwo for two periods in leading East Java. His decision to contest in the 2018 Election added to the long record of his political career. Prior to becoming Deputy Governor, he also had the chance to carry out his duties as Minister of Developing Underprivileged Regions during President Soesilo Bambang Yudhoyono reign.

He had a sympathetic character. In this context, courtesy directed the practice of political communication, which did not try to attack the opponent and preferred to use collective terms. He used the term "Mas" to greet Emil as his political opponent. 
"Mas," in the context of the Javanese social strata, is assumed as someone older. In this context, Gus Ipul greeted Emil indirectly by name, but he used the sublime term in Javanese culture. The use of the term "All are comradeship" and "All are prosperous" indicates that the candidate's presentation wanted to resemble himself as a person who protected all people. He did not try to distance himself from political opponents and the public.

During the debate, Gus Ipul did not provide any direct attacking arguments. He further emphasized the humanist side by opting for a religious and nationalist approach. This approach manifested through several terms, namely "moral education," faith refinement, when delivering vision and mission emphasizing the terms "harmony" and "maintaining harmony." The diction choice was related to the background of Gus Ipul as a santri who was very close to Nahdliyin's culture. The relation of religious and nationalism spirit was the primary basis in governance. He possesses high selfconfidence. This personal belief is inseparable from his appointment as a Deputy Governor for two periods. Overwhelmingly, the position was relatively very advantageous, considering that number of issues debated was inseparable from the problems faced by East Java Province during his time as a deputy governor. Gus Ipul tried to position himself as a part of the incumbent's success to continue to lead East Java again. He did not touch on sensitive matters but instead tried to clarify some critical statements made by opponents. When Khofifah-Emil highlighted the magnitude of poverty, he responded by clarifying that poverty had declined at a macro level during his leadership with Soekarwo.

In general, the narratives developed by Gus Ipul prioritized the values of optimism in building East Java's future. He tried to build a gap where his leadership was positive and deserved to be appreciated, so it needed to continue with the same programs to continually improve its quality. The terms "Sustainable change," "Win with dignity," "Competitiveness" were chosen to represent a commitment to build East Java better. In addition, this commitment supports persuasive diction favored by the lower-class community, such as "Serving the people," "Prospering together" as well as "Cooperation," through understanding the integration of reality on the ground and down-to-earth public jargon into the political communication strategy used by Gus Ipul. Therefore, he tried to minimize the existence of outside resistance or the emergence of opponents.

\section{Puti Guntur Soekarno - Confrontative Nationalists}

Puti Guntur Soekarno is a nationalist. She ordained herself to be one of Sukarno's successors. The highlighted national spirit in giving argumentation was supported by her courage when giving criticism to opponents. The ideology of struggle presented as a narrative of partiality among marginalized groups. She had a track record as a member of the Indonesian Parliament and PDIP politician. Her appointment as a Deputy governor candidate accompanying Gus Ipul was surprisingly unnoticed. However, this appointment is inseparable from the brand that the incumbent wanted to bring, particularly fulfilling nationalist-religious elements. Gus Ipul was able to represent the perspective of religious groups, while Puti was assigned to fill the nationalist perspective.

Furthermore, Puti emerges as the heir of Soekarno's nationalism. This condition was evident from the term used by Puti when the debate took place by stating, "Being a messenger of people." It became apparent that the statement conveys as a closing statement, offered to the public as an emphasis win the vote. She was critical, 
confrontational, and made an effort to attack and criticize the policies carried out by her political opponent, Emil, who became Khofifah's partner. She also aimed to explore and open up Emil's weaknesses when he led Trenggalek Regency. Puti's criticism became a negation as an attempt to bring down all achievements shown by Emil. Even to the extreme, her statements tended to be provocative, which encouraged Emil to respond emotionally, such as "Misappropriated data", "Please check the numbers," "Do not just look at the statistics," and "Do not yell." She led to talk about economic and political struggling problems, and she used many conventional approaches to convey public aspirations as an experienced member of the House. In this position, Puti developed a persuasive message by highlighting Gus Ipul government achievements and trying to position herself as a part of the public when "Connecting the People's Wish" like her grandfather Soekarno.

She positions herself as a reflection of "Millenials", close to the world of communication, information, and technology. The program she designed with Gus Ipul was MAS METAL (Digital Literacy Society). Although Emil's criticism provoked this program, it was assumed to be designed as an adaptive effort to respond to development challenges. The digital context is a necessity that must be addressed by every candidate for the state administrator in governance.

\section{Perception Contestation}

The debate of East Java Governor and Deputy Governor candidate pairs directed specific issues. These issues include: a) economics and welfare; b) the integration between the diniyah education system and the formal education system; c) the alignment of national policies; d) demographic bonuses; e) women violence and discrimination; f) salt-sand resource management, and renewable energy; g) investment potentials and creation of job opportunities; h) spatial-based and infrastructure development; i) millennial and youth; $j$ ) the industrial revolution and the disruptive trends; k) meritocracy government, and; 1) inter-sector communication, including attitudes in facing victory or defeat in political contestation.

The debate over people's welfare issues derives from the goal of global leadership. Khofifah viewed people's welfare by saying that the breath to build East Java was the breath to build the nation's culture and civilization. East Java people were the successors to the greatness and glory of the archipelago. East Java requires influential leaders, a stable government, and reliable people. Superiority in East Java could not be achieved if the people are poor, illiterate, and less healthy.

Meanwhile, Gus Ipul explained that the nature of people's welfare was comradeship and prosperity. The government is determined to realize East Java, where citizens felt all comrades and prosper. The adopted strategy was to make superior human resources as the foundation. Then, cooperation, collaboration, innovation were the means, and the people were the main forces. As a result, the government was able to overcome poverty and inequality, improve health and education, glorify women and children and the elderly, and build a good relationship amid society with harmony, upholding morality, and maintaining harmony to prosper East Java in unison.

The perception of the two candidates, in general, had similarities. However, Khofifah emphasized that people's welfare could be achieved if the leader could empower his people actively and places the territory he led as the center of civilization. The people's welfare from the perspective of Gus Ipul was when all members of the community lived together and could help one another achieve prosperity communally.

The debate on the second issue was related to the integration of diniyah education 
and the formal education system. Gus Ipul responded to the issue by demonstrating the program's success during his administration, such as increasing teacher resources. Together with Puti, he wanted to continue the program with Madin Plus program. For Khofifah, the madrasa was placed as a potential required to be supported by the province. Along with Emil, she made a number of criticisms for Gus Ipul-Puti. The criticism revolved around the limited bargaining value of religion-based schools due to the lack of government support. It was added with Emil's presentation, which criticizes Puti when she became a member of Commission X, which oversaw related fields. She was considered unable to overcome the main problem.

Different views regarding other issues also emerged. In the context of understanding demographic bonus, youth issue, and job vacancy, Khofifah-Emil had more control by showing factual data. Those were also Emil's concern in innovation and knowledge. Emil said that the education range at the age of 13-15 years was good, but it was low at 16-18 years. The offered solution was Bhakti: Working East Java. One of them was a Millennial Job Center, which was adaptive to advancements in the digital age.

Furthermore, Khofifah explained that she had visited several industrial centers and had witnessed a shortage of workers, thus making it a critical employment issue. Khofifah said $21 \%$ of East Java residents over the age of 15 had not graduated from elementary school, and 30\% had only graduated from elementary school, which result in increasing "unskilled labor." At the same time, some of them chose to become migrant workers.

Apart from that, Gus Ipul-Puti emphasized more conventional approaches and included contemporary discourse such as empowering start-ups in their program. They still put forward programs such as the internet entering villages and practical training in employment. In line with the view expressed by Gus Ipul, the provincial government necessitates efforts to promote workforce with particular skills and certification, which could be achieved via formal-informal education and training. Furthermore, Puti explained demographic bonuses and millennial challenges. The SUPERSTAR program was the solution to empower the millennial community through MSMEs, Start-ups, and other business centers. Puti also explained that she would ensure the internet and technology could be accessed throughout East Java.

Differences in perception also occurred when responding to issues of violence against women. Through Scouts, Gus Ipul toured 38 districts in East Java to highlight the rise of early marriage. He thought teens were still not ready to get married early and bear the economic burden. However, Khofifah did not emphasize reality facts, but she would instead offer alternative solutions after meeting with women and children networks. Some of the solutions include formulating the concept of integration and involving psychologists and campuses as partners supported by relevant local regulations. Khofifah was quite strategic in response to the East Java government's progressing program. She did not try to reject or criticize the related program; instead, she reminded that the program ended in 2018. Thus, it needed to be improved with a more innovative program, from the Jalinmatra program to be Satya East Java.

The battle between the two candidates was related to their educational background, experience, and political gait. Several other topics such as salt management, sand resource development, investment, spatial planning based on regional spatial planning, renewable energy, infrastructure development, economic growth, the era of disruption and the industrial revolution, mall administration, 
government meritocracy, and inter-sector communication took place. Hence, Gus IpulPuti party had put more effort into maintaining programs that were already running and relatively non-revolutionary. Meanwhile, Khofifah-Emil tried to position themselves to give criticism and provided alternative offers. In terms of the attitude of facing the victory or defeat in political contestation, the two sides relatively had the same response. It was only Khofifah-Emil who seemed more optimistic since Khofifah had been nominated as Governor but failed twice. Nevertheless, Gus Ipul-Puti's party seemed calmer under Gus Ipul's view in which he competed with dignity and accepted all results.

\section{Ideology Contestation}

Ideology contestation involves candidates' character and political affiliation. Khofifah-Emil was promoted by Democratic Party, Golkar, PAN, Hanura, NasDem, and PKPI. Meanwhile, Gus Ipul-Puti faction was supported by the Partai Demokrasi Indonesia Perjuangan (Indonesian Democratic Party of Struggle), PKB, Gerindra, and PKS. As mentioned in each candidate's profile, Khofifah was positioned as a bureaucrat, academician, and politician, while Emil was positioned as a professional, politician, and academic. Gus Ipul was positioned as a bureaucrat and politician, while Puti was positioned as a politician.

Khofifah and Gus Ipul, in the context of ideology, were relatively attached to Islam values because they were both from the background of Nahdatul Ulama. This mass organization prioritizes the values of Islamic nationality. Emil was a Kyai descendant, and foreign education helping his thought patterns and attitudes were closer to the global (Western) world. If Emil was closer to the Western world, then Puti was more directed to nationalism as the figure of Soekarno - her grandfather.

In principle, the ideological battle was generally relatively balanced. Both of them reinforced the national Islamic political narrative, and only Khofifah-Emil offered a more rational view regarding the presented parameters and empirical data in responding to debates. In this case, it demonstrates that the ideology of each candidate pair involving political affiliation (political parties) and the candidate's character (candidate's background) influenced the political discourse or narration delivered by each candidate during the Public Debate.

\section{Conclusion}

To conclude, the two candidates for Governor and Deputy Governor of East Java in 2018 had their political rhetoric strategies in persuading prospective voters when the Public Debate took place by proposing visions, missions, and programs with packaging or metaphors. They performed personal branding following their respective characters: Khofifah as a 'Visionary Courtesy' personal - with the background of Nadhatul Ulama (NU) 's Muslim figure; Emil Dardak as an 'Intellectual professional' personal - with the background of international workers and intellectual doctoral degrees; Gus Ipul as a 'Nationalist religious' personal - with the background as Nadhatul Ulama (NU) 's santri leader; Puti as a 'confrontational nationalist' personal - with the background as a granddaughter of Sukarno. In the contestation perception, Khofifah-Emil couple offered alternative ideas to overcome the problem, while Gus Ipul-Puti pair offered the continuation of the previous program (incumbent Gus Ipul). In the ideological contestation, the two candidate pairs of Khofifah-Emil and Gus Ipul-Puti were relatively under their political affiliations (political parties), the candidates' character (personal background); nationality-based santri (Khofifah and Gus Ipul), western revolutionary 
thinking (Emil), and nationality-nationalist (Puti).

This study has limitations on exploring metaphors and satire used by each pair of candidates for the Governor and Deputy Governor to refute or criticize each opponent in the 2018 East Java Public Debate. It is expected that further research will investigate the use of metaphors and satire by politicians to refute or criticize opponents in Public Debates. Alternatively, a quantitative-based public opinion survey could also be employed to uncover the effectiveness of politicians' rhetoric in persuading prospective voters during Public Debates.

\section{Acknowledgements}

Financial support for this research was fully provided by a grant from FISIP Universitas Brawijaya. The authors wish to thank Prof. Unti Ludigdo as a Dean of FISIP Universitas Brawijaya for supporting the author in researching this topic. Thanks are also due to Verdy Virmantoro and Dicky Wahyudi for their assistant in preparing the script of this debate.

\section{References}

Atkins, J., \& Finlayson, A. (2013). “... A 40-Year-Old Black Man Made the Point to Me": Everyday Knowledge and the Performance of Leadership in Contemporary British Politics. Political Studies. 3 (4), 445-464. https://doi.org/10.1111/j.14679248.2012.00953.x

Bligh, Michelle C., Kohles, Jefrey. C and Miendl, James R., (2004). Charisma under crisis: Presidential leadership, rhetoric, and media responses before and after the September $11^{\text {th }}$ terrorist attacks, Leadership Quaterly, 15 (2), 211-239, https://doi.org/10.1016/j.leaqua.2004.02.005.

Fairclough, N., \& Fairclough, I. (2013). Political discourse analysis: A method for advanced students. In Discourse \& Society.

Finlayson, A. (2007). From beliefs to arguments: Interpretive methodology and rhetorical political analysis. British Journal of Politics and International Relations. https://doi.org/10.1111/j.1467-856X.2007.00269.x

Finlayson, A. (2012). Rhetoric and the political theory of ideologies. Political Studies. 60 (4), 751-767. https://doi.org/10.1111/j.1467-9248.2012.00948.x

Finlayson, A. (2013). Critique and political argumentation. Political Studies Review. 11 (3), 313-320. https://doi.org/10.1111/1478-9302.12023

Finlayson, A., \& Martin, J. (2008). It aint what you say and: British political studies and the analysis of speech and rhetoric. British Politics. 3 (4), 445-464. https://doi.org/10.1057/bp.2008.21

Fischer, F. (2003). Reframing Public Policy: Discursive Politics and Deliberative Practices. In Reframing Public Policy: Discursive Politics and Deliberative Practices. https://doi.org/10.1093/019924264X.001.0001

Fischer, F., \& Gottweis, H. (2013). The argumentative turn in public policy revisited: Twenty years later. Critical Policy Studies. 7 (4), 425-433. https://doi.org/10.1080/19460171.2013.851164

Gottweis, H. (2017). Rhetoric in policy making: Between logos, ethos, and pathos. In Handbook of Public Policy Analysis: Theory, Politics, and Methods. https://doi.org/10.4324/9781315093192-28

Hay, C. (2013). Political discourse analysis: The dangers of methodological absolutism. Political Studies Review. 11 (3), 321-227. https://doi.org/10.1111/1478- 
9302.12026

Husain, M. N. (2011). Penerapan Komunikasi Politik dalam Penetapan Peraturan Daerah Kota Kendari. Jurnal ASPIKOM. 1 (3), 211-222. https://doi.org/10.24329/aspikom.v1i3.20

Kriyantono, R. (2006). Teknik Praktis Riset komunikasi - Rachmat Kriyantono, S.Sos., M.Si - Google Books. Kencana Prenada Media Group.

Martin, J. (2015). Situating Speech: A Rhetorical Approach to Political Strategy. Political Studies. 63 (1), https://doi.org/10.1111/1467-9248.12039

Neuman, W. L. (2013). Social Research Methods: Qualitative and Quantitative Approaches, 7th Ed, Harlow: Pearson Education Limited.

Soedjatmiko, (11 April 2018), Pengamat: Khififah-Emil Unggul di Debat Perdana Pilgub Jatim. Jawa Pos, diakses dari: https://www.jawapos.com/nasional/pemilihan/11/04/2018/pengamat-khofifahemil-unggul-di-debat-perdana-pilgub-jatim.

Struever, N. (1993). The Rhetorical Turn: Invention and Persuasion in the Conduct of Inquiry. Journal of the Institute for Vico Studies. https://doi.org/10.5840/newvico19931120

Sulaiman, Y. (2014), More rhetoric, less substance in Indonesia's presidential debates, The Converstation, accessed on Januari 2021, https://theconversation.com/morerhetoric-less-substance-in-indonesias-presidential-debates-28400.

Tilly, C., \& Goodin, R. E. (2006). The Oxford Handbook of Contextual Political Analysis. In The Oxford Handbook of Contextual Political Analysis. https://doi.org/10.1093/oxfordhb/9780199270439.001.0001

Turnbull, N. (2017). Political rhetoric and its relationship to context: a new theory of the rhetorical situation, the rhetorical and the political. Critical Discourse Studies. 14 (2), 115-131. https://doi.org/10.1080/17405904.2016.1268186

Walter, R. (2016). Rhetoric or Deliberation? : the case for rhetorical political analysis, Political Studies, vol 65, 2, pp 300-315. https:/doi.org/10.1177/0032321716651898 